\title{
Histological examination of structural changes in the cochlear canal
}

\author{
Koklear kanaldaki yapısal değişikliklerin histolojik incelenmesi
}

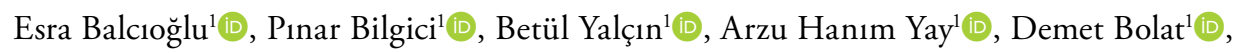 \\ Ayşe Ceyhan ${ }^{3}$ (i), Mehmet Akif Somdaş² (i) \\ ${ }^{1}$ Department of Histology and Embryology, Erciyes University, Faculty of Medicine, Kayseri, Turkey \\ ${ }^{2}$ Department of Otolaryngology, Erciyes University, Faculty of Medicine, Kayseri, Turkey \\ ${ }^{3}$ Pathology Laboratory Techniques Program, Tokat Gaziosmanpaşa University, Vocational School of Health Services, Tokat, Turkey
}

\begin{abstract}
Objectives: In this study, we aimed to determine the morphological changes in the organ of Corti in the basal, medial, and apical regions of the cochlear canal, which exhibit a complex structure.
\end{abstract}

Materials and Methods: A total of eight male Wistar albino rats (35 days, 200 to $250 \mathrm{~g}$ ) were decapitated under anesthesia. The organ of Corti was quickly removed and fixed in $10 \%$ formaldehyde solution for histological examination. The tissues were, then, taken to decalcification solution. Following dehydration and clearing, they were embedded in paraffin. Sections were stained with hematoxylin \& eosin and Masson's trichrome, and photographs were captured using a light microscope. To determine the structural changes in the organ of Corti, basilar, tectorial, and Reissner membrane lengths, and heights of inner and outer hair cells were measured from 50 different areas using the Image $\mathrm{J}$ software and the data obtained were statistically evaluated.

Results: It was determined that from the basal to the apex of the cochlea; the thickness of the basement membrane and the length of the Reissner's membrane decreased, while the length of the inner and outer hair cells and the length of the basement membrane increased. These increases and decreases were statistically significant $(\mathrm{p}<0.05)$.

Conclusion: Our study results suggest that the lengths of inner and outer hair cells, basilar, and Reissner membrane can vary from basal to apical region of the cochlea.

Keywords: Cochlea, light microscope, organ of Corti.
$\ddot{O Z Z}$

Amaç: $\mathrm{Bu}$ çalışmada kompleks bir yapı sergileyen koklear kanalın bazal, medial ve apikal bölgelerinde korti organındaki morfolojik değişiklikler belirlendi.

Gereç ve Yöntemler: Toplam sekiz Wistar Albino cinsi erkek sıçan (35 günlük, 200-250 g) anestezi altında dekapite edildi. Korti organı hızla çıkarıldı ve histolojik inceleme için \%10 formaldehit solüsyonu içinde tespit edildi. Sonrasında dokular dekalsifikasyon solüsyonuna alındı. Dehidrasyon ve temizlemenin ardından parafine gömüldü. Kesitler hematoksilen- eozin ve Masson trikom ile boyandı ve $1 s ̧ ı k$ mikroskobu ile fotoğrafları çekildi. Korti organındaki yapısal değişiklikleri belirlemek için baziler, tektorial ve Reissner membran uzunlukları ile iç ve dış saçlı hücrelerin boyları Image J yazılımı kullanılarak 50 farklı alanda ölçüldü ve elde edilen veriler istatistiksel olarak değerlendirildi.

Bulgular: Kokleanın bazalından apeksine doğru gittikçe; bazal membran kalınlığı ve Reissner's membran uzunluğunu azalırken, iç ve dış saçlı hücrelerin uzunlukları ile bazal membran uzunluğunun arttığı belirlendi. Bu artış ve azalışlar istatistiksel olarak anlamlılık seviyesindeydi $(\mathrm{p}<0.05)$.

Sonuç: Çalışma sonuçlarımız, iç ve dış saçlı hücrelerin, baziler ve Reissner membran uzunluklarının kokleanın bazalinden apikal bölgesine kadar farklılık gösterebileceğini öne sürmektedir.

Anahtar sözcükler: Kohlea, ışık mikroskobu, korti organı. 
The ear, the organ responsible for hearing and balance, consists of three parts: the outer, middle and inner ears whose functions and structures are different from each other. ${ }^{[1]}$ The inner ear is the part of the receptors related to hearing and balance ${ }^{[1-3]}$ and is located deep in the petrous part of the temporal bone. ${ }^{[4,5]}$ The cochlea, which resembles a snail in the front of the inner ear, is located in the bone labyrinth. Bone labyrinth is formed by compact bone tissue called otic capsule. ${ }^{[6]}$ The cochlea is a bone pathway that spirals around 2.5 turns around the modiolus forming the axis. The cochlea consists of three parts: scala tympani, scala media, and scala vestibule. The scala media is separated from the scala vestibule with the Reissner membrane and the scale tympani with the basilar membrane. The hearing organ, called the organ of Corti, is located in the scala media region and the neuroepithelium and support cells forming the organ of the Corti are settled on the basilar membrane. The neuroepithelial cells are composed of single-stranded inner hair cells and threestranded outer hair cells. The support cells are located around the neuroepithelial cells; Hensen, Deiters, Pillar cells, and Claudius cells have a complex structure. ${ }^{[6-8]}$

The cochlea can be defined as a delicate membranous cellular tissue network surrounded by the body's hardest bone tissue. Due to the anatomical structure, the different morphological characteristics of the cells and tissues and technical difficulties in evaluation, detailed investigations on cochlea morphology have been left behind.

It is well established that high frequency sounds are perceived in the basal and low frequency sounds are perceived in the apical part of the cochlea.
As the length increases in wind instruments, the sound becomes thicker. The sound of a short flute is much thinner than a long one. In this context, the higher the frequency (fine) of the sound wave entering through the oval window, the more vibration it warns at the basal. However, the smaller the area diameter of a drum, the finer the sound. The diameter of the basal crimp is known to be thicker than the apex. However, since thin sounds are detected in the basal, the cells and membranes of interest are expected to be short and small in diameter. ${ }^{[9]}$

In the present study, we aimed to investigate the cellular changes occurring in the cortical organ at the level of light microscopy to gain a better understanding of the basic mechanism of hearing physiology.

\section{MATERIALS AND METHODS}

Between November 2019 and February 2020, a total of eight male Wistar Albino rats (35 days, 200 to $250 \mathrm{~g}$ ) obtained from Erciyes University Experimental Research Application and Research Center were used. The study protocol was approved by the Erciyes University, Faculty of Medicine, Ethics Committee (No: 19/210). All rats were decapitated under anesthesia. The rats' heads were dissected by entering through the foramen magnum, and the parietal bones were cut to the end and both sides of the head (16 ears) were removed. The external ear canal was also cut to make the cochlea apparent. The entry point of the cochlear nerve was taken to the center and the cochlea protruding into the middle head pit and the middle ear was fixed and excess bone surrounding the tissues were removed with the help of fine-tipped scissors. In this way, the

\begin{tabular}{|ll} 
& Table 1 \\
& \\
Cell and structures & Evaluation criteria \\
\hline Reissner membrane & Histological evaluation of epithelium and microvillus structure/length measurement \\
Stria vaskülaris & Histological evaluation of multilayer squamous epithelium \\
Thickness of basilar membrane & Histological evaluation of connective tissue/measurement of thickness \\
Length of basilar membrane & Histological evaluation of connective tissue/length measurement \\
Cladius cells & Histological evaluation \\
Boettcher cells & Histological evaluation \\
Hensen cells & Histological evaluation \\
Deiter's cells & Histological evaluation \\
Pillar cells & Histological evaluation \\
Stereocilia & Histological evaluation of outer hair cells/length measurement \\
Tectorial membrane & Histological evaluation of inner hair cells/length measurement \\
\hline
\end{tabular}


vestibule connection was opened and the vestibule was removed.

Following fixation, the bone tissue was softened in a solution consisting of $80 \mathrm{~mL}$ distilled water $+10 \mathrm{~mL}$ formaldehyde $+10 \mathrm{~mL}$ nitric acid for decalcification. The tissues were, then, washed under running tap water and dehydrated by being passed through increasing alcohol series. Dehydrated tissues were cleared with xylene, and the cochlea was embedded in paraffin in a horizontal position and subjected to routine paraffin procedures. Five- $\mu$ m thick serial sections were taken from the paraffin blocks, deparaffinized and rehydrated, stained with hematoxylin and eosin (H-E) and Masson's trichrome (MT), and examined under a light microscope. According to the prespecified criteria (Table 1), 50 different areas were measured in each region with the Image J version 1.45 program (National Institutes of Health, Bethesda, MD, USA).

\section{Statistical analysis}

Statistical analysis was performed using the IBM SPSS version 22.0 software (IBM Corp., Armonk, NY, USA). Descriptive data were expressed in mean \pm standard deviation (SD) and number, where applicable. The normal distribution of numerical variables was analyzed using the Shapiro-Wilk test. Comparisons between the groups were made by one-way Analysis of Variance (ANOVA) for the variables with normal distribution, while the Tukey test was used for multiple comparisons. A $p$ value of $<0.05$ was considered statistically significant.

\section{RESULTS}

In a histological image obtained from the light microscope, the scale media region was separated

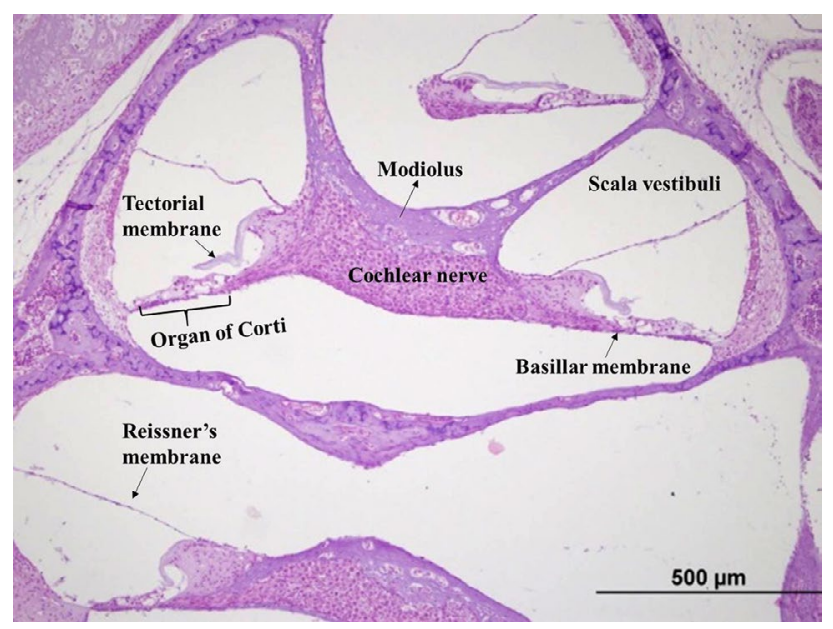

Figure 1. Light microscopic images of cochlea $(\mathrm{H}-\mathrm{E}, \times 10)$. other compartments from basement membrane and Reissner membrane. The basilar membrane is a complex fibrous connective tissue structure containing cellular and extracellular compounds and acts as a mechanical analyzer that senses the frequency of sound. On the modiolus side, the membrane structure
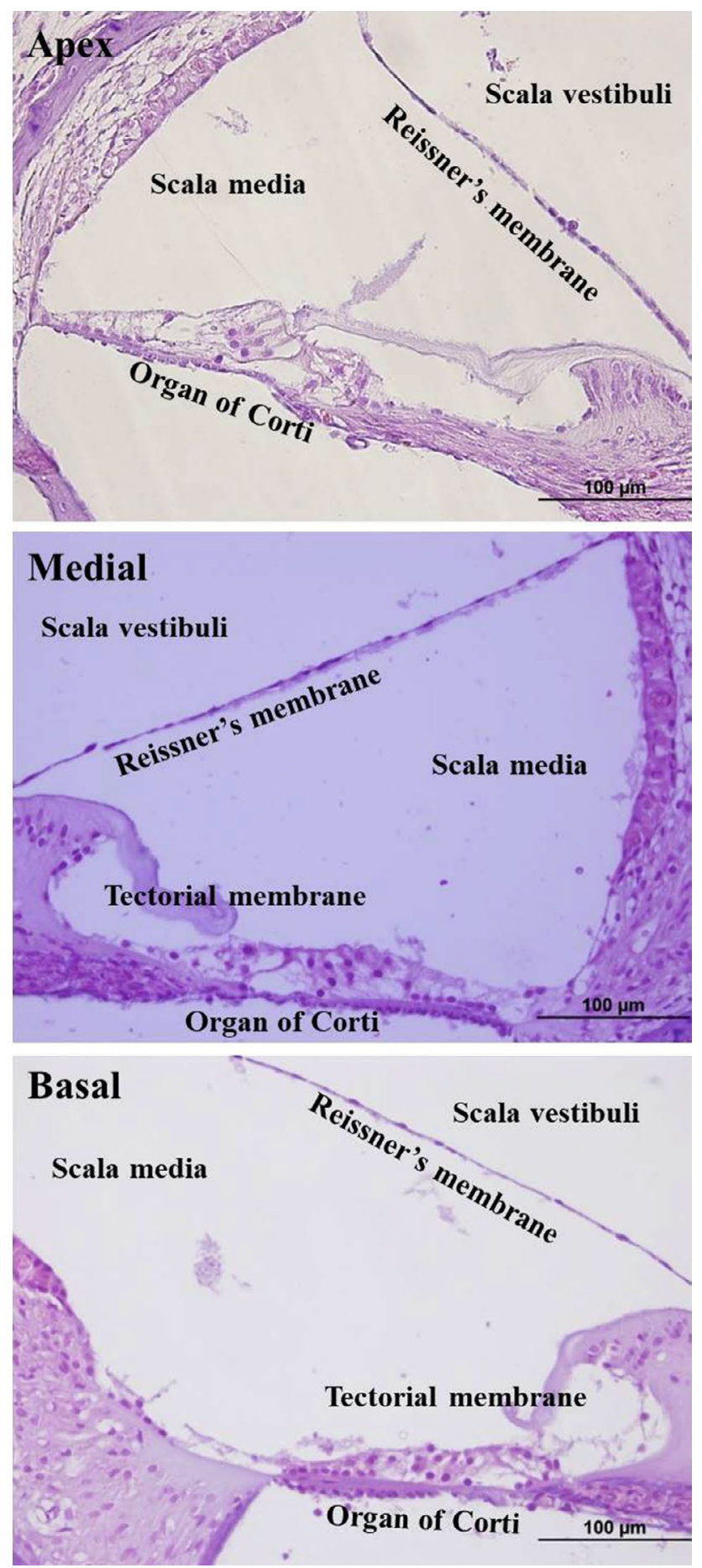

Figure 2. Light microscopic images of Corti $(\mathrm{H}-\mathrm{E}, \times 40)$. 


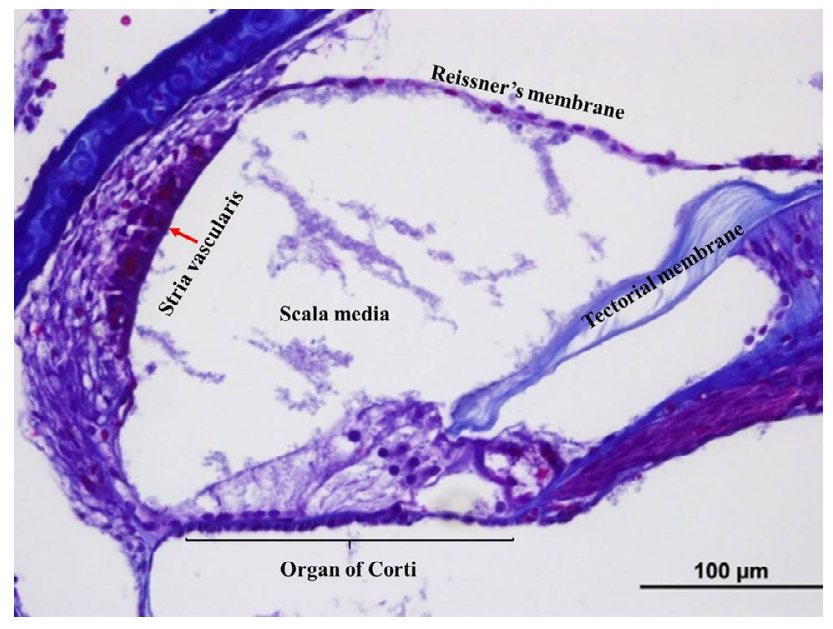

Figure 3. Light microscopic images of Corti $(\mathrm{MT}, \times 40)$.

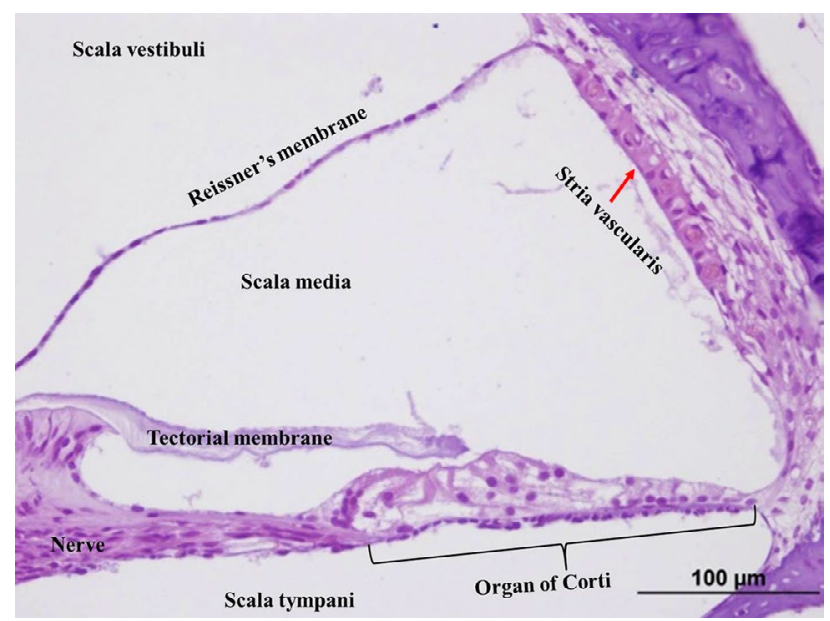

Figure 4. Light microscopic images of Corti $(\mathrm{H}-\mathrm{E}, \times 40)$.

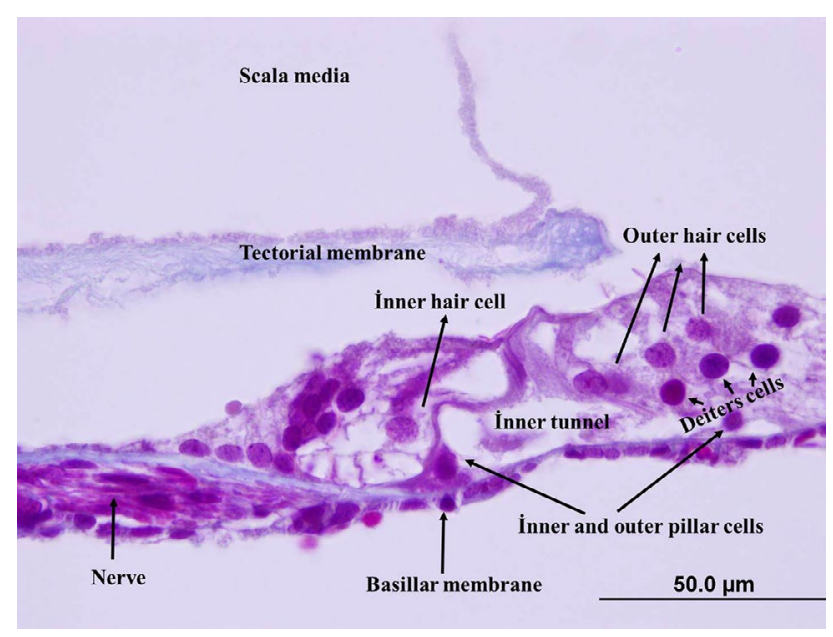

Figure 5. Light microscopic images of Corti $(\mathrm{H}-\mathrm{E}, \times 100)$. around the modiolus in the center extended from the osseous spiral lamina to the stria vascularis region on the outside. When the histological structure of the cortical organ was examined at large magnification, it consisted of hair cells and support cells located on the basilar membrane. The cells located in a single row formed the inner hair cells and the cells in three rows formed the outer hair cells. At the base of the inner and outer hair cells, Deiters cells were observed which sent tall and face cytoplasmic extensions which could be easily distinguished by round and distinct nuclei structures. When the 2.5 turn of the cochlea was examined from the basal to the apex, the length of the cells and the length of stereocilia became longer and the width of the basement membrane increased (Figures 1-5).

In addition to the histological findings, the measurement results were statistically evaluated. The length and width of the basilar membrane, the length of the Reissner membrane, and total length of outer and inner hair cells with Deiters cells in the cortical organ and the length of the tectorial membrane were included in the measurement. Accordingly, the length of the Reissner membrane, which forms the division between the scale vestibuli and the scale media, gradually decreased from basal to apex and this decrease between the regions was statistically significant $(p<0.05)$. To determine the change in the width of the basilar membrane located at the base of the cortical organ, the mean values were obtained by measuring from three different regions. The mean values were $14.9 \pm 4.1 \mu \mathrm{m}$ in the baseline, $14.4 \pm 3.9 \mu \mathrm{m}$ in the media, and $11.6 \pm 3.1 \mu \mathrm{m}$ in the apex, indicating no statistically significant difference between the basal and media ( $p>0.05)$. When the mean basilar membrane length was evaluated, the increase between the three regions was found to be significant $(p<0.05)$. When the length measurements obtained from the Deiters cells were examined, the increase in the mean values from basal to apex was determined based on the results of the measurements, and this increase was statistically significant $(p<0.05)$. Outer hair cells located in three rows were measured separately from each of the Deiters cells. When the mean values were examined, the lengths increased from basal to 's apex. When the obtained data were evaluated statistically, there was a significant difference between the mean values obtained from all three regions $(\mathrm{p}<0.05)$ (Table 2$)$.

\section{DISCUSSION}

Detailed information on cochlea morphology is far behind other sensorineural systems due to the complexity of its anatomical structure, the different morphological 


\begin{tabular}{|c|c|c|c|c|c|}
\hline Basal, media, and a & Ireme & $\begin{array}{l}2 \\
\text { f the cells loc }\end{array}$ & in the cortica & & \\
\hline & & Basal & Medial & Apex & \\
\hline Measuring areas & $\mathrm{n}$ & Mean \pm SD & Mean \pm SD & Mean \pm SD & $p$ \\
\hline Thickness of basilar membrane & 150 & $14.9 \pm 4.1^{\mathrm{a}}$ & $3.9 \pm 3.9^{\mathrm{a}}$ & $11.6 \pm 3.1^{b}$ & \\
\hline Length of outer hair cells + deiter's cells & 150 & $29.1 \pm 4.8^{\mathrm{a}}$ & $35.2 \pm 4.4^{\mathrm{b}}$ & $40.6 \pm 5.9^{c}$ & \\
\hline Length of reissner membrane & 50 & $480.7 \pm 54.6^{a}$ & $422.0 \pm 43.0^{\mathrm{b}}$ & $385.6 \pm 45.6^{c}$ & $<0.05$ \\
\hline Length of basilar membrane & 50 & $145.4 \pm 19.1^{\mathrm{a}}$ & $161.1 \pm 15.9^{b}$ & $179.5 \pm 15.7^{c}$ & \\
\hline Length of inner hair cells + deiter's cells & 50 & $29.6 \pm 4.7^{\mathrm{a}}$ & $33.7 \pm 4.5^{b}$ & $39.6 \pm 4.5^{c}$ & \\
\hline
\end{tabular}

characters of its cells, and tissues and technical difficulties in evaluation. Cochlea can be defined as a delicate membranous tissue network suspended in liquids and surrounded by the hardest bone tissue of the body. It requires specialized methods to evaluate and investigate inner ear tissues. To explain the basic mechanism of hearing physiology, the main aim of our study was to determine the perception of sounds of different intensities in the basal, media, and apex of the cochlea depending on the structural changes in the organ of Corti in these regions. According to the previous studies, the mean length of the stria vascularis was $25.22 \mathrm{~mm}$ and its width decreased toward the floor of the cochlea. ${ }^{[10-15]}$ In our study, there was a shortening of the length of stria vascularis from the basal to the apex.

The mean length of the basilar membrane has been found to be $31.5 \mathrm{~mm}$ in humans, $18.8 \mathrm{~mm}$ in guinea pigs, and $18.3 \mathrm{~mm}$ in chinchillas in studies regarding Corti. ${ }^{[16,17]}$ It has been reported that the width of basilar membrane from the basal to the apex increases from $150 \mu \mathrm{m}$ to $450 \mu \mathrm{m}$ in humans, from $150 \mu \mathrm{m}$ to $250 \mu \mathrm{m}$ in guinea pigs, and from $230 \mu \mathrm{m}$ to $370 \mu \mathrm{m}$ in chinchilla. ${ }^{[16,17]}$ Unlike previous studies, we measured the mean length and width of the basilar membrane in the basal, medial, and apex in our study. The results showed that, from the basal to the apex, the thinning in the width of the basilar membrane and the increase in its length were significant.

Boettcher cells function as supportive cells in the organ of Corti. It was shown that the number of these cells from the basal to the apex decreased in parallel with our results. ${ }^{[11,12]}$ In the light of the literature data, locating cells in the organ of Corti are larger at the apex than basal, and that stereocilia are also elongated. In addition, the basement membrane expands and the density of the mass of the tectorial membrane increases. ${ }^{[4,8,11-20]}$ The length of outer hair cell is reported to be 10 to $80 \mu \mathrm{m}$ and the number of stereocilia is approximately 100 to $120 .^{[8,12,21,22]}$ According to previous studies, the length of the outer hair cell changes along the cochlea and is shorter in the basal region, compared to the apical region. Histologically, outer hair cells are supported by Deiters cells from basal and apical with outer pillar, Deiters and Hensen cells. ${ }^{[8,12,21,22]}$

In the present study, we observed an elongation in the length of the outer and inner hair cells from the basal to the apical. Tectorial membrane is a non-cellular connective tissue mass covering the organ of Corti from the basal to the apex and the stereocilia of outer hair cells attach to the tectorial membrane and inner hair cells. In the light of these data, it can be concluded that the mass of the tectorial membrane increases in contrast to the frequency ratio along the cochlear canal. These findings are also in consistent with previous studies in the literature. ${ }^{[23-26]}$

In conclusion, the width of the basilar membrane, which plays an important role in the formation of sound, decreases and its length increases from the basal to the apex and a systematic increase is found in the length of the outer and inner hair cells, showing a primary function in hearing. The shorter cells at the base of the cochlea are the region where higher frequencies are received. Tall cells at the apex of the cochlear canal are the peak where low frequencies are converted. Based on these findings, we consider that the physiology of hearing is directly parallel to the change in cells. However, further studies are needed to confirm these findings.

\section{Declaration of conflicting interests}

The authors declared no conflicts of interest with respect to the authorship and/or publication of this article.

\section{Funding}

The authors received no financial support for the research and/or authorship of this article. 


\section{REFERENCES}

1. Akyıldız AN. Kulak Hastalıkları ve Mikrocerrahisi. 1. Cilt. Ankara: Bilimsel Tip Yayınevi; 1998.

2. Karasalihoğlu AR. Kulak Burun Boğaz Hastalıkları ve Baş-Boyun Cerrahisi. Ankara: Güneş Kitabevi; 2003. s. 3-14.

3. Donaldson JA, Duckert LG. Anatomy of theears. In: Paparella MM, Shumrick DA, Gluckman JL, Meyerhoff WL, editors. Otolaryngology Head and Neck Vol. 1, 3rd ed. Philadelphia: WB Saunders Co; 1991. p. 23-58.

4. Chen WC, Jackson A, Budnick AS, Pfister DG, Kraus DH, Hunt MA, et al. Sensorineural hearing loss in combined modality treatment of nasopharyngeal carcinoma. Cancer 2006;106:820-9.

5. Kopelman J, Budnick AS, Sessions RB, Kramer MB, Wong GY. Ototoxicity of high-dose cisplatin by bolus administration in patients with advanced cancers and normal hearing. Laryngoscope 1988;98:858-64.

6. Santi PA, Mancini P. Kohlear anatomi ve santral işitme yolları. In: Koç C, editör. Cummings Otolaringoloji Baş ve Boyun Cerrahisi. 4. Cilt. Ankara: Güneş Tip Kitabevleri; 2007. s. 3373-97.

7. Arıncı K, Elhan A. Kulak, işitme ve denge organları anatomisi. Anatomi. Ankara: Güneş Kitapevi; 1997. s. 466-90.

8. Raphael Y, Altschuler RA. Structure and innervation of the cochlea. Brain Res Bull 2003;60:397-422.

9. Poyrazoğlu E, Güngör A, Uğur G, Okar İ, Candan H. Ototopikal siprofloksasinin koklear etkilerinin taramali elektron mikroskopisi ile gösterilmesi. K.B.B. ve Baş Boyun Cerrahisi Dergisi 1997;5:116-21.

10. Dallos P. Overwiev; Cochlear Neurobiology. In; Dallos P, Popper AN, Fay RR, editors. The Cochlea. 1st ed. NewYork: Springer; 1996. p. 1-44.

11. Santi PA, Tsuprun VL. Cochlear Micro anatomy and Ultrastructure. In: AF Jahn, JS-Sacchi, editors. Physiology of the Ear. 2nd ed. San Diego; Singular \& Thomson Learning; 2001. p. 257-81.

12. Slepeckly NB. The cochlear structure. In; Dallos P, Popper AN, Fay RR, editors. The Cochlea. 1st ed. NewYork: Springer; 1996; p. 44-130.
13. Donaldson JA, Duckert LG. Anatomy of the ears. In: Paparella MM, Shumrick DA, Gluckman JL, Meyerhoff WL, editors. Otolaryngology. Vol. 1. 3rd ed. Philadelphia: WB Saunders Co; 1991. p. 23-58.

14. John HM, Waren YA. Anatomy and phsiology of hearing. In: Bailey BJ, editor. Otolaryngol Head Neck Surgery Vol. 2. Philedelphia: JB Lippincott Co; 1993. p. 1441-61.

15. Harrison RV, Mount RJ. The Sensory Epithelium of The Normal and Pathological Cochlea. In: Jahn AF, S-Sacchi J, editors. Physiology of the Ear. 2nd ed. San Diego; Singular \& Thomson Learning; 2001. p. 285-99.

16. Wysocki J. Topographical anatomy of the guinea pig temporal bone. Hear Res 2005;199:103-10.

17. Sehitoğlu MA, Uneri C, Celikoyar MM, Uneri A. Surgical anatomy of the guinea pig middle ear. Ear Nose Throat J 1990;69:91-7.

18. Ryan AF. New Views of Cochlear Function. In; Robinette MS, Glattke TJ, editors. "Otoacoustics emissions" Clinical applications. 2nd ed. New York: Thieme Medical Press; 2002. p. 49-94.

19. Lee KJ. Anatomy of the ear. Essential Otolaryngology Head and Neck Surgery. 8 th ed. New York: Medical Publish Co; 2003. p. 1-24.

20. Ashmore J. Biophysics of the cochlea - biomechanics and ion channelopathies. Br Med Bull 2002;63:59-72.

21. Kachar B, Brownell WE, Altschuler R, Fex J. Electrokinetic shape changes of cochlear outer hair cells. Nature 1986;322:365-8.

22. Brownell WE, Bader CR, Bertrand D, de Ribaupierre Y. Evoked mechanical responses of isolated cochlear outer hair cells. Science 1985;227:194-6.

23. Robles L, Ruggero MA. Mechanics of the mammalian cochlea. Physiol Rev 2001;81:1305-52.

24. Dallos P. The active cochlea. J Neurosci 1992;12:4575-85.

25. Oghalai JS. The cochlear amplifier: augmentation of the traveling wave within the inner ear. Curr Opin Otolaryngol Head Neck Surg 2004;12:431-8.

26. Zheng J, Anderson CT, Miller KK, Cheatham M, Dallos P. Identifying components of the hair-cell interactome involved in cochlear amplification. BMC Genomics 2009;10:127. 